\title{
Climate Change and Public Health Situations in the Coastal Areas of Bangladesh
}

\author{
Russell Kabir ${ }^{1}$, Hafiz T.A. Khan ${ }^{1}$, Emma Ball ${ }^{2}$, Kay Caldwell ${ }^{3}$ \\ ${ }^{1}$ Department of Economics and International Development, Middlesex University, London, UK \\ ${ }^{2}$ Department of Product Design and Mathematics, Middlesex University, London, UK \\ ${ }^{3}$ Department of Health and Education, Middlesex University, London, UK \\ Correspondence: Russell Kabir, Department of Economics and International Development, Middlesex University, \\ London NW4 4BT, UK.
}

Received: May 31, 2014

Accepted: June 12, $2014 \quad$ Available online: July 4, 2014

doi:10.11114/ijsss.v2i3.426

URL: http://dx.doi.org/10.11114/ijsss.v2i3.426

\begin{abstract}
This study aims to investigate the population health of climate change affected people in the coastal areas of Bangladesh. The relationship between climate change and health lacks clarity in the existing literature. This study uses data collected from the area affected by cyclone Sidr in 2009. Results show that climate change triggered natural disasters such as Sidr can is affect the physical and mental health of this population. The prevalence of diarrhoea, skin diseases, dengue fever, hepatitis (jaundice) and other infectious diseases has increased after the natural disaster. The risk of injury and death also increased during the time of natural disaster. Children and older adults are the most vulnerable groups facing serious health problems including mental health. The majority of the health professionals, service providers and local community of coastal areas are more aware of the health impacts of climate change, yet their knowledge is limited regarding health protection measures.
\end{abstract}

Keywords: Climate Change, Bangladesh, Cyclone, Health Impact, Infectious diseases, vulnerable population

\section{Introduction}

Human health depends on the natural environment and its ecosystem and our environment is changing rapidly at global, national and local level. The quality and the quantity of our natural environment have been deteriorating and the main reasons for these changes are anthropogenic. According to IPCC (2007) anthropogenically the driven climate change will increase the rate of environmental change, worsening the situation. On World Health Day 2008 the theme highlighted "protecting health from climate change" and which stated that changing patterns of climate are likely to affect the human health including vector borne diseases, safe drinking water, secure shelter, food supply and social relations (WHO, 2008). According to McMicheal et al. (2009:2123) "climate change arises in the context of a world that is now experiencing systemic disruptions to environment- and hence risk to health, wellbeing and social functioning. To address climate change, public health should therefore consider risks at whole population level."

The health of populations depends on the constant steadiness and execution of the planet's ecological and physical systems, commonly denoted as life-support systems (McMichaeal, 2003). The United Nations Environment Programme (UNEP) suggests "poor environmental quality is directly responsible for some 25 per cent of all preventable ill health worldwide" (UNEP, 2002:306). The World Health Organization (WHO) reports that every year "about 1.2 million people die from causes attributable to urban air pollution, 2.2 million from diarrhoea largely resulting from lack of access to clean water supply and sanitation, and from poor hygiene, 3.5 million from malnutrition, and approximately 60,000 in natural disasters" (WHO, 2009:2). Research also showed evidence of climate change effects on vector-borne and other infectious diseases (Haines et al., 2006). It is now evident that vector borne diseases are responding to recent climate change in Europe (Purse et al., 2005). Due to latitudinal shifts there is growth of tick-borne encephalitis in northern Europe (Lindgren et al., 2000; Skarphedinsson et al., 2005). In 2003, a heat wave in Europe was an extreme event and the summer of the same year was probably the hottest in Europe since 1500 (Luterbacher et al., 2004). According to the climatologists human induced global climate change was responsible for such a heat wave in 2003 (Stott et al., 2003). Increases in the intensity of tropical cyclones are also due to climate change (Emanuel, 2005; Webster et al., 2005). Recently Japan was hit by earthquake and tsunami across the enfolds of its eastern coast and The 
Fukushima Daiichi nuclear power plant was severely damaged by this earthquake and tsunami and was the world's worst nuclear accident in 25 years (The Telegraph, 2011). According to The Daily Mail Reporters (2010) climate change could spark more volcanoes, earthquakes and tsunamis (Mail Online, 2010). Globally places such as, Japan is more vulnerable to natural disasters and climate calamities like Haiti. In the year 2011, about 28,000 people died in the Japan earthquake (CRED EM DAT, 2011).

In the USA, Hurricane Katrina caused major damage to the coastlines of Louisianna, Mississippi and Alabama in 2005 (Haines et al., 2006) and most recently on $30^{\text {th }}$ November 2012 hurricane Sandy hit along across the US East Coast causing huge damage to the country's economy including a great loss of lives of 50 peoples (The Telegraph, 2012). According to scientists of the American Geological Society, climate change is likely to have made hurricane Sandy much more worse than it would have been by the Huffington Post (2012).

\section{Context and the Settings}

Health and wellbeing are the basic rights for all mankind depend largely on a healthy biosphere with a stable ecosystem. These pillars of human health are at greater risk due to climate change (Doha Declaration, 2012). The extent and severity of climate change varies, however, it is extreme in some countries because of their geographical position such as Bangladesh (Rahman et al., 2011). Due to its geographical setting it is very easy to destroy and damage the ecological balance of Bangladesh (Salequzzaman \& Stocker, 2001). Bangladesh is a small country in South Asia with a population of almost 162 million (WHO, 2011). Mountains and hills covering three-fourths of the country and the funnel shaped Bay of Bengal in the south have made the country more vulnerable to natural disaster. Bangladesh has been plagued by innumerable natural disasters over the years. Tropical cyclones, tidal surges, tornados, floods, droughts and river erosion are the main natural disasters that the country has faced. The Bay of Bengal is one of the regions in the world that is disposed to cyclone and the cyclonic disturbances; these are five to six times higher in the Bay of Bengal compared to the Arabian Sea. This is due to the fact that Sea Surface Temperature (SST) over the Arabian Sea is cooler than that of the Bay of Bengal (Alam, 2012). According to UNDP (2010) statistics, about four percent of the world's cyclones hit Bangladesh. Coastal areas, especially heavily populated mega delta regions in South, East and South-East Asia, will be at greatest risk due to increased flooding from the sea (IPCC, 2007). The Global Climate Risk Index 2013 by German Watch (2012) listed Bangladesh in 4th position in the climate risk index and the most vulnerable nation going to be affected by the changing climate after Honduras, Myanmar and Nicaragua respectively. Bangladesh was hit by the world's most devastating cyclone to date in 1970, which caused 500000 deaths (WHO \& WMO, 2012). Higher population density increases vulnerability to climate change especially water related disaster in Bangladesh (Agrawala et al., 2003). Over a period of 100 years, 508 cyclones have affected the Bay of Bengal region, of which 17 percent made landfall in Bangladesh. A severe cyclone occurs almost once every three years. Although the frequency of cyclones is not unusual compared to other cyclone hotspot countries, the impact it causes stands out: 53 percent of the cyclones that claimed more than 5,000 lives took place in Bangladesh (GOB, 2008).

Table 1. The major cyclones over Bangladesh at a glance

\begin{tabular}{lrrrr}
\hline \multicolumn{1}{c}{ Date and } & Year & $\begin{array}{c}\text { Maximum wind } \\
\text { speed }(\mathrm{km} / \mathrm{hr})\end{array}$ & $\begin{array}{c}\text { Storm surge } \\
\text { Height }(\text { meter })\end{array}$ & Death toll \\
\hline May 11 & 1965 & 161 & $3.7-7.6$ & 19,279 \\
15 December & 1965 & 217 & $2.4-3.6$ & 873 \\
01 October & 1966 & 139 & $6.0-6.7$ & 850 \\
12 November & 1970 & 224 & $6.0-10.0$ & 300,000 \\
25 May & 1985 & 154 & $3.0-4.6$ & 11,069 \\
29 April & 1991 & 225 & $6.0-7.6$ & 138,882 \\
19May & 1997 & 232 & $3.1-4.6$ & 155 \\
15 November & 2007 & 223 & $6.1-9.1$ & 3,363 \\
25May & 2009 & 170 & $5.2-10.0$ & 400 \\
\hline
\end{tabular}

(Source: Bangladesh Meteorological Department, 2009)

Using metrological data (temperature and rainfall) from 1983-2009 in rural Bangladesh, the recent study shows that weather has been found to be strongly associated with mortality with differential impacts in age and gender (Lindeboom et al., 2012). History shows that there are two peak in the annual distribution of tropical cyclones in the Bay of Bengal one is pre-monsoon in April-May and the other one is post monsoon in October-November and during 1891-1990, Bangladesh was hit by 700 cyclones, of which 62 occurred in pre-monsoon and 192 in post-monsoon season (Shamsuddoha and Chowdhury, 2007). 


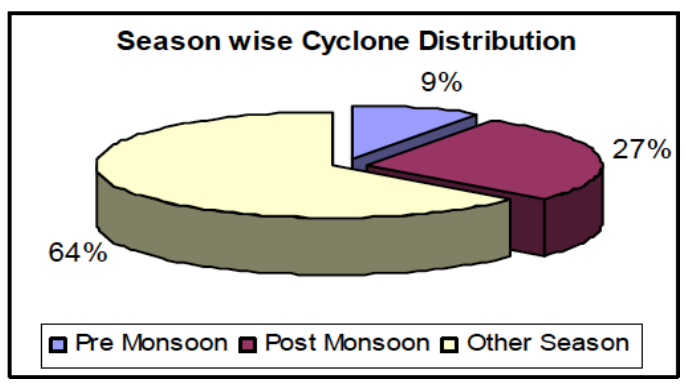

Source: (Shamsuddoha and Chowdhury, 2007:18)

Figure 1. Season wise Cyclone Distribution

In recent times, Bangladesh was hit by two consecutive cyclones Sidr in 2007 and Aila in 2009. Paul (2009) found that cyclone Sidr hit Bangladesh on $15^{\text {th }}$ November 2007 and caused 3,406 deaths and over 55,000 sustained physical injuries. Heavy rains accompanying cyclones and tidal waves due to wind effects have caused extensive physical destruction, casualties, damage to crops, livestock and flooding in a total of 30 districts across the south western coastal district of Bangladesh (Ministry of Flood \& disaster Management, 2008). Cyclone Sidr affected nine districts of Bangladesh; the most devastated districts were Bagerghat, Barguna, Patuakhali and Pirojpur (Davidson, 2008). After Sidr, the Government of Bangladesh (2008) carried out a rapid initial assessment and found there were massive outbreaks of waterborne disease, respiratory tract infection (RTI) and other related infections with people in the nine surveyed areas being at risk of communicable diseases including diarrhoea, dysentery, acute respiratory infection and pneumonia. Children age five years or younger were the most vulnerable (Ministry of Flood \& disaster Management, 2009).

Cyclone Aila hit the southern coastline of Bangladesh hard in May 2009. This resulted in an outbreak of diarrhoeal disease in the cyclone Aila-hit coastal areas of Khulna as an acute scarcity of drinking water and food worsened the sufferings of thousands. Although there were no official data available on the Diarrhoeal deaths, approximate figures of 15 deaths have been reported by the locals in Koyra, Paikgacha and Dacope (Roy et al., 2009). Cyclones today have become a major portrait of climate change. According to the IPCC tropical cyclones and extreme weather events are due to greenhouse gas mitigation efforts. Emanuel (2005) stated that the intensity of cyclones has increased in the last 30 years. Yet the relationship between cyclones and climate change is argumentative, may be because it's a rare event and problematic to discover changes in causal frequencies and severity (Landsea et al., 2006). Like other disasters, direct health impacts of cyclones include deaths and injuries. Some of the important indirect health impacts include significant outbreaks of communicable, water-related and other diseases, such as diarrhoea, hepatitis, malaria, fever, pneumonia, eye infections, and skin diseases.

The key aim of this research is to assess the public health situation of people due to cyclone Sidr in the coastal areas of Bangladesh. To fulfill the broad aim, the study has the following specific objectives: i) to examine the potential influences of climate change on infectious diseases, including vector- and rodent-borne diseases and water- and food-borne diseases in Bangladesh; ii) to investigate how climate change affects the health status of the household members; iii) to identify the impacts of climate change on various vulnerable groups such as children and older adults; and finally, iv) to investigate the socio-economic condition of the affected population.

\section{Methodology}

This is a pilot research and mainly focused on small group population. This study was conducted in the South West part of Bangladesh. Cyclone Sidr hit Bangladesh's offshore islands at approximately $6: 30 \mathrm{pm}$ on the evening of $15^{\text {th }}$ November 2007. Bangladesh is divided into six administrative divisions; three of these divisions Barisal, Khulna and the capital city Dhaka were severely affected by cyclone Sidr.

These divisions are subdivided into altogether 64 districts. Of the twelve worst affected districts, six districts are in Barisal, three in Khulna and three in Dhaka (GoB, 2008). Barguna was the worst hit district by cyclone Sidr. Barguna district was also affected by severe cyclones in 1935, 1965, and 1970 (Tamima, 2009). During Sidr, most of its flood ridges were washed away and the people are faced with the daily difficulty of tidal seawater engulfing their land (Reliefweb, 2009). Baliatali village of Amtali upazila of Barguna was selected for data collection. At least 128 people were killed in Barguna district during 2007 cyclone and 77 of them were from Amtali upazila (NIRAPAD, 2007).

Qualitative methods were used to collect the data. Qualitative research normally takes place in a natural setting (Denzin, 1971), which helps to capture a more credible feel of the situation that cannot be explained through using numerical data and statistical analysis. The data collection process started with the help of local Union council members. Data were collected in the middle of July 2010. Focus group Discussion (FGD) was conducted in the Sidr affected area in 
Amtali upazila of Barguna District. For data collection, different government and non-government institutions were informed beforehand, care was taken to find a convenient time and place for the meeting and research purpose was made clear to the participants and full consent was taken prior to the discussion. The researcher moderated the sessions and two other associates were involved in note taking and recording the conversation. The qualitative data were collected by using focus group discussion (FGD) from the following two groups of respondents.

Group 1: Consists of only service providers from Upazila and Union level (a union has on average 20,000 people). The target participants were Upazila organizer of NGOs, Executive Director of Emergency Response, Technical Officer of Dhaka Ahsania Mission, Cluster Team Leader of Notun Jibon Programme (Social Development Foundation), and Registered Medical Officer of Upazila Health complex, Upazila Agricultural Officer, Upazila Administrator, Health Assistant of Union, and Junior Assistant Director of Bangladesh Red Crescent Society- Cyclone Preparedness Programme.

Group 2: This consists of former and current UP (Union Porishod) members, farmers, businessmen, social workers, fishermen, BRAC (Bangladesh Rural Advancement Committee) health workers and housewives.

Several government and non-government organizations are working in the cyclone affected area. For each FGD a maximum of 10 persons, one from each organization working in the affected area was selected. As the participants were non-English speakers, the interview guide was translated into Bengali. Written consent was taken from the participants before recording the interviews and played back to them. During the interviews the researcher used the Bengali language, which was again translated into English by the researcher for the purpose of analysis. Respondents were found to have tremendous memories of the Sidr experience. The following steps insured the validity and reliability of the data collection instrument. Firstly a thorough literature review has been carried out related to climate change, health and natural disasters. Secondly the experts in the field of climate change and public health verified the interview guide for the Focus Group Discussion. To attain accuracy and reliability of the data, care and caution were taken during data collection. The participants were found to be co-operative and simple language was used for smooth flow of the discussion. The present research being a pilot one has of course some limitations, for example, in selecting small number of respondents and selection of qualitative method. However, future research may focus on a larger sample which will help avoiding selection bias in the results.

\section{Main Results}

The collected data were analyzed through the thematic analysis. Four themes were developed as follows: The first theme proposes climate change and its impact on health. The second theme influences of infectious diseases due to climate change, the third theme discussed the impact of climate change on the vulnerable people of the community and the fourth theme highlighting about the socio-economic situation of affected population.

\subsection{Climate Change and Its Impact on Health}

The FGD started with the question on the impact of climate change on the health of the community. Specifically, the main aim was to get information from the participants about the cyclone had impact on health (such as the general health situation, mental health and wound) during Sidr and after Sidr. To understand the magnitude of the problem, information on the health condition of the community people before Sidr was also gathered for comparison. Several participants gave their opinions on the issue and these include: During Sidr the people of Amtali, Barguna suffered from various diseases such as diarrhoea, dysentery, virus fever, cough, cold, skin disease, eye problem, pain, paralysis, Jaundice, lack of nutrition, waterborne diseases, typhoid, anaemia, high blood pressure, severe headache were the most common. When questions on the current general health situation of the community were raised vast majority of the participants mentioned that the health situation of the community people were reasonably better now compared to immediately after Sidr. The health situation has improved because of different program interventions by different agencies but it has taken long time to reach this situation. According to, the participants the health situation has become normal as before Sidr.

When, questioned about the mental health situation of the community and the majority of the participants reported that after Sidr the mental health situation was back to normal but their livelihood had not been improved. Their mental health situation is now better than it was during Sidr. According to one participant from the community, "A 50 year old lady and 3 females of 30-40 years age had become mentally instable after the incident of cyclone. They have lost all their family members, households, personal belongings."

The majority of people mentioned that injuries were common during Sidr. In Amtali, many people were struck by tin (which is used to build houses in rural area), trees and as a result many broke their legs, hands, cut different parts of the body, and injured their head. Some people even died after being hit on the head by tin or falling tree. The number of wounded persons was high during Sidr. During, Sidr high volume of water washed away people and boats and other hard objects wounded them. Currently many of the wounded persons are suffering from different kinds of side effects. Some of them became disabled due to the injury at the time of the cyclone. 
Illnesses like diarrhoea, food poisoning, skin diseases, respiratory problem, pneumonia, and dengue fever are now seen were rare before the occurrence of Sidr but are now more prevalent. The diseases are being observed after the occurrence of cyclone Sidr that has caused by the climate change in the area. Women members of the family had to face so much hardship during this time. Adolescent girls are having menstrual period as early as 11 years old than before informed by the registered medical officer of the upazila health complex. These diseases were less in the past than it is seen now.

\subsection{Climate Change and Infectious Disease}

The participants in the FGD mentioned that the infectious diseases increased after the occurrence of Sidr. The most commonly seen infectious diseases in the area are diarrhoea, typhoid, skin disease, and chicken pox. After Sidr lack of clean water and unclean environment caused skin diseases, water borne disaeses and chicken pox. However, chicken pox is also a seasonal disease. During winter cough cold, pneumonia cases were common and during the rainy seasons skin diseases, cold and cough are also common. The participants in the FGD also mentioned that about 20-30\% people suffered from these diseases. They also mentioned that about $15 \%$ people suffered from diarrhoea and chicken pox just immediately after Sidr. Among the affected people about 3\% were children aged less than five years old who were dying of diarrhoea. All the participants agreed that number of affected people was higher after the occurrence of Sidr than it was pre Sidr. At, present the situation has improved because of different interventions taken by both Government Organizations (GO) and Non-government Organization (NGOs). Diarrhoeal diseases are now under control.

According to the participants the main sources of these infectious diseases are polluted and high salinity of water, unhealthy sanitation, unclean environment, unclean food, excessive hot weather and vector borne insects. Due to climate change natural calamity is now common in these areas, which changes natural the environment and more viral diseases are emerging that were not common 20 years ago in the area. For the prevention of the diseases both GO and NGOs are working in the affected area. They introduced new deep tube wells for safe drinking water, constructed hygienic toilets, distributed of water purifying tablets, bleaching powder, cleaned pond water were undertaken by different agencies. They also distributed general medicines to the people of the community. The above-mentioned services to the community the health situation is returning to where it was before the cyclone hit the area.

Generally people go to hospital for treatment of Pneumonia, diarrhoea, viral fever, jaundice, chicken pox, sexual disease, dysentery, skin disease, peptic ulcer, eye problem, malnutrition, typhoid, stomach upset and physical wound. These ailments were also common before the occurrence of Sidr but the prevalence was lower than it is now after Sidr.

\subsection{Climate Change and Vulnerable Population}

One of the participants from the officials said: "Children aged less than five years old and people aged 60 years and above are most at risk due to climate change”. They are now surviving somehow against the adverse environment after the occurrence of Sidr. In some areas, the health situation has deteriorated due to Sidr. Many children and aged people have become disabled due to injury during the cyclone. They are now in a helpless situation. During the tidal surge, many children died and aged people are in worse condition than they were before the occurrence of Sidr. Many are surviving against adverse situation but their health situation is getting worse day by day especially the older ones. One of the participants from the service providers said: 'Because of the occurrence of Sidr, many elderly people are now suffering from eyesight problem, back pain, virus fever, and physical weakness. Cough \& cold, dysentery, skin disease, jaundice, common fever and typhoid are a regular feature in the Sidr affected areas'

As a result many people have cuts in hand and leg, broken hand and leg, cut in the head, injury to different parts of the body, wound in the waist etc. Many died as a result of injuries sustained by being hit by falling trees and houses collapsing. According to opinions of the participants, child death after the natural disaster has increased. These children died mainly from diarrhoea, Pneumonia, and injury related causes. The main reasons of elderly death were due to diabetes, hypertension and blood pressure. Vaccination coverage in the affected area was reasonably good because according to the participant's immunization coverage was above $90 \%$ in their community. According to them, few percentages of children were not immunized because their parents were not motivated about the importance of child immunization.

\subsection{Climate Change and Socio-economic Situation}

The participants stated that all agricultural products were damaged due to natural disaster. The riverbank erosion destroyed the farming lands, salinity in the water has increased and production of agriculture has declined tremendously. Houses are broken; poultry production totally wrecked, fishes in the ponds are dying, educational institutions shattered, due to the salinity of the water grasses are not growing and livestock were not getting enough food. There was a severe shortage of food; many were suffering from malnutrition especially the children and women. However, none died due to lack of food. Relief was available in abundance. Food scarcity in the area is still a major concern for the local community people. Following the occurrence of Sidr, there was lack of employment in the affected area. In some areas there were opportunity for work but working people were not available as they were busy rebuilding their own houses.

The affected people also went through financial hardship. They lost their all valuables including the houses during the 
disaster and the agricultural land was not suitable for growing crops immediately after Sidr. There is not enough employment opportunity in the area and most of the people in the area are farmers and fishermen. They are living in very poor conditions. However, many GO and NGOs are working to bring back normalcy. The economic condition of the affected area was at its worse just after the Sidr. The people were having a normal life before the cyclone hit the area. So many villagers went through mental trauma due to poverty after the occurrence of Sidr. Many were sick due to poverty because Sidr destroyed their house, agriculture production and they lost all kinds of household assets. So many members of the family died from the attack of Sidr. From the above findings; it is quite clear that the Sidr affected Amtali people of Barguna region went through some serious health problems. Losses of property and close relatives have made them mentally unstable. Lack of food and clean water has increased their sufferings. Many people were injured by the cyclone and the lack of job opportunities in the area has made their life more miserable after Sidr. The prevalence of infectious diseases and other diseases have increased dramatically after the climate change. Children and older people are the most affected group in this calamity. Things are improving for the people in Amtali. Various government organizations and non-government organizations are working hand in hand to return the normal life of these people and rates of poor health due to Sidr are coming down. Since all these poor health conditions have been observed after Sidr, it shows that the natural disaster like cyclone due to changing climate has some impact on the people of Amtali of Barguna.

\section{Discussion and Conclusion}

The objective of this research has been to assess the impact of climate change on human health in Bangladesh. A large number of studies suggested that there is an impact of climate change on human health in Bangladesh. Climate change is a new concept in environmental health research. Bangladesh with its populated land close to sea level is at particular risk. The study revealed that affected the population by cyclone Sidr have faced many diseases like diarrhoea, typhoid fever, respiratory problem, pneumonia, hepatitis (jaundice), death and injury and mental health problems. The result of this study has shown consistency with the findings of other studies. For example just after the 1991 Bangladesh cyclone, UNICEF Cyclone Evaluation team has reported increase in diarrhoea incidence compared to pre-cyclone rates and almost all death in the affected areas occurred as a result of drowning from the tidal wave that accompanied the cyclone(UNICEF, 1991). Myint et al. (2011) reported diarrhoea, dysentery and acute respiratory infections (ARI) increased just after the Cylone Nargis affected areas in Myanmar.

This study reveals that children and the older people are the most vulnerable group during the time of a natural disaster; the children and older adults are facing more serious health consequences due to climate change. Bhuiyan and Khan (2011) found with available evidence that the climate change is affecting the health of the older populations of Kazakhstan and making them sensitive to climate change.

Some diseases are emerging in the affected community like dengue fever due to climate change in Bangladesh. Similar situation happened post cyclone Nargis period in Myanmar where the dengue incidence slightly raised (Myint et al., 2011). The socio-economic situation of the affected population was in poor state after the cyclone hit the area and due to lack of employment opportunities and infrastructural support these people had to face long term health consequences due to climate change. Waiyaki et al. (2012) found that the residents of Faza Island of Kenya has been struggling with their social and economic lives due to climate change which is effecting their local environment (both land and sea) and as a result they are finding it hard to meet their subsistence needs. Things are improving now as various local government and non-government organizations are working there and people are getting back to their normal life. A majority of the health professionals, service providers and local community of the coastal areas of Bangladesh are aware of the health impacts of climate change but their knowledge regarding health protection measures is limited. Government and other non-government organizations can take measure to control health related problems in the affected area. Coping with climate change related health problems at the rural is important for every individual so actions should be taken on building resilience and strengthening the health systems at all rural level. Various training programme can help the communicate people to get to know more about the climate change and its impact on human health. This research shows that it would be useful to investigate in greater detail with a large sample or from more diverse group about the other factors of climate change that have an impact on health. In addition, climate change is a complex phenomena and its impact on human health is obvious but to explore the relationship require further investigation.

\section{Acknowledgement}

I would like to thank Professor Dr. M. Kabir and Dr. M. Shahjahan for their influential guidance and support for this research project.

\section{References}

Agrawala, S., Ota, T., Ahmed, A. U., Smith, J., \& Aalst, M. (2003). Development and Climate Change in Bangladesh: Focus on the Coastal Flooding and Sundarban. OECD, Head of the publication service, 75775 Paris, Cedex 16, France. 
Alam, M, S. (2012). Tropical Cyclones in Bangladesh. Edited By Ahmed, R., \& Shamsuddin, S.D. in Climate Change: Issues and Perspective for Bangladesh. Shahitya Prakash, Dhaka, Bangladesh.

Bhuiyan, S. H., \& Khan, T.A. (2011). Climate change and its impacts on older adults health in Kazakhstan. The Nispacee Journal of Public Administration and Policy, IV; 1, 97-119.

Cred-emdat (Centre For research on the epidemiology of disaster emergency events database). (2011): The OFDA/CRED International Disaster Database. Université Catholique de Louvain. Brussels, Belgium. [Online] Available at: http://www.emdat.be [Accessed date 09/12/2012]

Davidson, S. (2008). A Review of the IFRC-led Shelter Coordination Group Bangladesh Cyclone Sidr Response 2007-2008. [Online]. Available from: http://www.humanitarianreform.org/humanitarianreform/ [Accessed date $13 / 09 / 2011]$.

Denzin, N. K. (1971): The Logic of Naturalistic Inquiry. Social Force, 50, 166-182.

Doha, D. (2012). Health must be central to climate action, COP18, December 2012. [Online]. Available from: http://dohadeclaration.weebly.com [Accessed date 08/12/2012]

Emanuel, K. (2005). Increasing destructiveness of tropical cyclones over the past 30 years. Nature; 436:686-88.

German watch. (2012). Global Climate Risk Index 2013. Bonn,Germany.

GoB. (2008). Cyclone Sidr in Bangladesh: Damage loss and Needs Assessment for Disaster Recovery and Reconstruction. Dhaka, Bangladesh.

GoB. (2008). Super Cyclone Sidr 2007: impacts and strategies for interventions. Dhaka.

Haines, A., Kovats R., S., Campbell-Lendrum, D., \& Corvalan, C. (2006).Climate change and human health: impacts , vulnerability and mitigation. The Lancet Series: 367:2101-09. [Online] Available from http://www.thelancet.com [Accessed date 02/07/2011]. http://dx.doi.org/10.1016/s0140-6736(06)68933-2

Huffington Post. (2012). Hurricane Sandy Damage Partly Caused By Climate Change, Scientists Say. [Online]. Available from: http://www.huffingtonpost.com/2012/11/06/hurricane-damage-climate-change_n_2081960.html [Accessed date 09/12/2012]

IPCC. (2007). Climate change 2007: Impacts, adaptation and vulnerability. Contribution of working group II to the Fourth Assessment Report of the Intergovernmental Panel on Climate Change. M.L. Parry, O.F. Canziani, J.P. Palutikof, P.J. van der Linden, C.E. Hansson (Eds.). Intergovernmental Panel on Climate Change (IPCC), Cambridge University Press, New York.

Landsea, C. W., Harper, B. A. Hoarau, K., \& Knaff, J. A. (2006). Can We Detect Trends in Extreme Tropical Cyclones? Science. 313; 452 - 454. http://dx.doi.org/10.1126/science.1128448

Lindgren, E., Tälleklint, L., \& Polfeldt, T. (2000). Impact of climatic change on the northern attitude limit and population density of the disease transmitting European tick Ixodes ricinus. Environmental Health Perspectives, 108, 119-23. http://dx.doi.org/10.1289/ehp.00108119

Lindeboom, W., Alam, N., Begum, D., \& Streatfield, P.K. (2012). The association of metrological factors and mortality in rural Bangladesh, 1983-2009. Global Health Action, 5, 61-73. http://dx.doi.org/10.3402/gha.v5i0.19063

Luterbacher, J., Dietrich, D., Xoplaki, E., Grosjean, M., \& Wanner, H. (2004). European seasonal and annual temperature variability, trends and extremes since 1500. Science, 303, 1499-1503. http://dx.doi.org/10.1126/science.1093877

Mail Online. (2010). Climate change could sparks more volcanoes, earthquakes and tsunamis. [Online] Available from: http://www.dailymail.co.uk/sciencetech/article-1267137/Climate-change-spark-volcanoes-earthquakes-tsunamis.ht $\mathrm{ml}$ [Accessed date 09/12/2012]

McMichael, A. J (2003). Climate Change and Human Health. World Health Organization, 1-306. [Online] Available from http://www.who/climatechange.com [Accessed date 02/07/2011].

McMichael, A., Neira ,M., Bertollini, R., Campbell-Lendrum, D., \& Hales., S. (2009). Climate change: a time of need and opportunity for the health sector. The Lancet: 374; 2123-25. [Online] Available from: http://www.thelancet.com. [Accessed date 02/07 /2011]. http://dx.doi.org/10.1016/s0140-6736(09)62031-6

Ministry of food and disaster management. (2009). Major natural disaster in Bangladesh [Online]. Available from: http://www.dmb.gov.bd/pastdisaster.html [Accessed date 25/09/2011].

NIRAPAD. (2007). Cyclone Sidr kills hundreds in Barisal and Khulna Division. [Online]. Available from: http://www.nirapad.org [Accessed date 19/12/2012]

Myint, N, W., Kaewkungwal, J., Singhasivanon, P., Chaisiri, K., Panjapiyakul, P., Siriwan, P, Malik, A, K., Nyein, S. L., 
$\& \mathrm{Mu}, \mathrm{T}$. T. (2011). Are there any changes in burden and management of communicable diseases in areas affected by Cyclone Nargis? Conflict and Health, 5, 9. http://dx.doi.org/10.1186/1752-1505-5-9

Paul, B. K. (2009). Why relatively fewer people died? The case of Bangladesh's cyclone Sidr. Natural Hazards, 50, 289-304. http://dx.doi.org/10.1007/s11069-008-9340-5

Purse, B. V., Mellor, P. S., Rogers, D. J., Samuel, A. R., Mertens, P. P., \& Baylis,M. (2005). Climate Change and the recent emergence of bluetongue in Europe. Nature Reviews Microbiology; 3, 171-81. http://dx.doi.org/10.1038/nrmicro1366

Rahman, M. S., Haque, M. M., \& Khan, M. B. K. (2011). Perception on Climate Change: An Exploratory Study on Urban Citizens. European Journal of Economics, Finance and Administrative Sciences, 31, 17-30.

Reliefweb. (2009). Bangladesh: Two years after Cyclone Sidr, survivors still seeking shelter [Online]. Available from: http://reliefweb.int/node/334287 [Accessed Date 17/09/2011].

Roy, K., Kumar, U., Mehedi, H., Sultana, T., \& Ershad, D. M. (2009). Initial Damage Assessment Report of Cyclone AILA with focus on Khulna District. Unnayan Onneshan-Humanity Watch- Nijera Kori, Khulna, Bangladesh, June 23, 2009. pp-31.

Salequzzaman, M., \& Stocker, L. (2001). The context and prospects for environmental education and environmental careers in Bangladesh. International Journal of Sustainability in Higher Education, 2(2), 104-127. http://dx.doi.org/10.1108/14676370110388309

Shamsuddoha, M., \& Chowdhury, K. M. (2007). Climate change impact and disaster vulnerabilities in the coastal areas of Bangladesh. [Online] Available from: www.coastbd.org ～[Accessed date 25/01/2013]

Skarphedinsson, S., Jensen, P. M., \& Kristiansen, K. (2005). Survey of tick borne infections in Denmark. Emerging Infectious Disease, 117, 1055-61.

Stott, P. A., Stone, D. A., \& Allen, M. R. (2004). Human contribution to the European heat wave of 2003. Nature, 432, $610-14$

Tamima, U. (2009). Population Evacuation Need Assessment in Cyclone Affected Barguna District. Journal of Bangladesh Institute of Planners, 2, 145-157. http://dx.doi.org/10.3329/jbip.v2i0.9575

The Telegraph. (2011). Japan earthquake, tsunami and Fukushima nuclear disaster: 2011 review. [Online] Available from: http://www.telegraph.co.uk/news/worldnews/asia/japan/8953574/Japan-earthquaketsunami-and-Fukushima-nuclear -disaster-2011-review.html\# [Accessed date 08/12/2012]

The Telegraph. (2012). Superstorm Sandy: Obama visits devastated New Jersey. [Online] Available from: http://www.telegraph.co.uk/news/worldnews/northamerica/usa/9642169/Hurricane-Sandy-live.html [Accessed date 26/11/2012]

UNDP. (2010). UNDP Bangladesh [Online]. Available from http://www.undp.org.bd/info/events.php?newsid=720. [Accessed date 13/09/2011].

UNEP (United Nations Environment Programme). (2002). Global Environment Outlook 3 Synthesis: Past, Present and Future Perspectives. London: EarthScan.

UNICEF. (1991). Health Effects of the 1991 Bangladesh Cyclone: Report of a UNICEF Evaluation Team. Disasters, 1993, 17, 153-165.

Waiyaki, E., Angwenyi H, O, R., \& Muriuki, T. (2012). An assessment of the percieved socioeconomic impacts of cliamte change on the community of Faza Island, Lamu East Distrcit, Kenya. Social Science Report Series No-35, 83-118.

Webster, P. J., Holland, G. J., Curry, J. A., \& Chang, H. R. (2005). Changes in the tropical cyclone number, duration and intensity in a warming environment. Science, 309, 1844-46. http://dx.doi.org/10.1126/science.1116448

WHO. (2008). Mental Health assistance to population affected by the Tsunami in Asia. Geneva, WHO. [Online] Available from: www.who.int/mentalhealth/resource/tsunami [Accessed date 11/02/2011]

WHO. (2009). Protecting Health from Climate Change: Connecting Science, Policy and People. Geneva, Switzerland: World Health Organization.

WHO. (2011). WHO Bangladesh. [Online] Available from: http://www.who.int/countries/bgd/en/ [Accessed date $12 / 09 / 2011]$

WHO \& WMO. (2012). Atlas of health and climate. Geneva, Switzerland, WHO.

\section{$(\mathrm{cc}) \mathrm{BY}$}

This work is licensed under a Creative Commons Attribution 3.0 License. 